\title{
Studi Komunitas Padang Lamun di Kecamatan Tanggetada, Kabupaten Kolaka, Sulawesi Tenggara
}

\author{
Study of Seagrass Beds Community at Tanggetada District, Kolaka Regency, \\ Southeast Sulawesi
Ilham Antariksa Tasabaramo ${ }^{1}$, Riska $^{1}$, Petrus C. Makatipu ${ }^{2}$, Aditya Hikmah Nugraha $^{3}$, Hasan Eldin Adimu ${ }^{1}$
${ }^{1}$ Program Studi Ilmu Kelautan, Universitas Sembilanbelas November Kolaka. Indonesia. ${ }^{2}$ Puslit Oseanografi LIPI, Jakarta. Indonesia \\ ${ }^{3}$ Program Studi Ilmu Kelautan, Universitas Maritim Raja Ali Haji. Kepulauan Riau. Indonesia \\ *Korespondensi: ilhamantariksa20@gmail.com
}

\begin{abstract}
ABSTRAK
Kecamatan Tanggetada memiliki areal padang lamun yang luas dan sering dimannfaatkan oleh masyarakat. Padang lamun di daerah ini belum terkonfimasi secara ilmiah baik itu dari jenis, kerapatan dan komunitas lamunnya. Penelitian ini bertujuan untuk mengetahui jenis dan kerapatan lamun di Kecamatan Tanggetada. Metode yang digunakan pada penelitian ini adalah metode transek kuadrat pada areal $100 \mathrm{~m} 2$ ditiap stasiun. Lokasi penelitian berada di 3 stasiun yaitu Stasiun 1 di Kelurahan Tanggetada, Stasiun 2 di Desa Palewai dan Stasiun 3 Kecamatan Anaiwoi. Hasil penelitian, ditemukan 6 jenis lamun tersebar di Kecamatan Tanggetada yaitu Enhalus acoroides, Thalassia hemprichii, Cymodocea rotundata, Halodule uninervis, Halophila ovalis, dan Syringodium isoetifolium. Kerapatan lamun termasuk dalam kategori rapat dan jarang. Stsiun 1 memiliki kerapatan lamun yang tinggi dengan ketegori rapat yaitu $160.46 \mathrm{ind} / \mathrm{m} 2$, kemudian Stasiun 2 dengan kerapatan lamun agak rapat yaitu 117.49 ind $/ \mathrm{m} 2$ dan Stasiun 3 dengan kerapatan lamun yang rendah dengan kategori jarang yaitu $60.59 \mathrm{ind} / \mathrm{m} 2$. Thalassia Hempricii merupakan lamun yang memiliki nilai kerapatan paling tinggi dibandingkan jenis lamun lainnya.
\end{abstract}

Kata Kunci: Lamun, Kerapatan, Thalassia Hempricii, Tanggetada.

\begin{abstract}
Tanggetada District has a large area of seagrass beds and is often used by the community. Seagrass beds in this area have not been scientifically confirmed, both in terms of species, density and seagrass communities. This study aims to determine the type and density of seagrass in Tanggetada District. The method used in this study is a quadratic transect method in an area of $100 \mathrm{~m} 2$ at each station. The location of the research was carried out at 3 stations, namely Station 1 in Tanggetada Village, Station 2 in Palewai Village and Station 3 in Anaiwoi Village. The results showed that 6 species of seagrass were found in Tanggetada District, namely Enhalus acoroides, Thalassia hemprichii, Cymodocea rotundata, Halodule uninervis, Halophila ovalis, and Syringodium isoetifolium. Seagrass density is included in the category of dense and rare. Station 1 has a high density of seagrass with a dense category of $160.46 \mathrm{ind} / \mathrm{m} 2$, then Station 2 with a rather dense seagrass density of $117.49 \mathrm{ind} / \mathrm{m} 2$ and Station 3 with a low density of
\end{abstract}


seagrass with a rare category of $60.59 \mathrm{ind} / \mathrm{m} 2$. Thalassia Hempricii is a seagrass that has the highest density value compared to other seagrass speciesseagrass density in the rare category. Thalassia Hempricii is a seagrass that has the highest density value compared to other seagrass species.

Keywords: Seagrass, Density, Thalassia Hempricii, Tanggetada.

\section{PENDAHULUAN}

Lamun merupakan tumbuhan berbunga yang hidup diperairan dangkal dan membentuk suatu organisasi ekologi dimana didalamnya terjadi interaksi biotik dan abiotik (Kiswara \& Hutomo, 1985; Azkab, 2006; Rahmawati et al., 2014).

Indonesia salah satu pusat keanekaragaman hayati di daerah indopacifik. Tercatat 13 spesies lamun yang ditemukan di perairan Indonesia dari 60 spesies lamun di dunia meliputi spesies Cymodocea rotundata, $C$. serrulata, Enhalus acoroides, Halodule pinifolia, Halodule uninervis, Halophila decipiens, $H$. minor, $H$. ovalis, $H$. spinulosa, $H$. sulawesii, Syringodium isoetifolium, Thalassia hemprichii dan Thalassodendron ciliatum (Kuo, 2007).

Secara ekologi, padang lamun memiliki peranan yang sangat penting, antara lain sebagai produsen primer, menstabilkan sedimen, daerah asuhan dan tempat mencari makan (Duarte et al., 2005; Supriadi et al., 2014; Koch et al., 2012; Christianen et al., 2014). Padang lamun juga memberi nilai manfaat langsung secara ekonomis melalui kegiatan penangkapan hasil perikanan, seperti Ikan baronang, lencam, cumicumi, dan kepiting (Oktawati, 2018). Menurut Wawo (2014), valuasi nilai ekonomi padang lamun sangat memberikan manfaat kepada masyarakat dengan menyediakan jasa ekosistem.

Kecamatan Tanggetada merupakan wilayah administrasi Kabupaten Kolaka yang terletak di perairan teluk Bone. Perairan Kecamatan Tanggetada memiliki areal padang lamun yang luas dan sering dimanfaatkan dan dieksploitasi oleh masyarakat setempat. Kurangnya pengetahuan masyaratkat terhadap fungsi penting padang lamun dapat mengancam ekosistem padang lamun. Menurut Vo et al (2013), luasan padang lamun indonesia telah mengalami penurunan dari tahun ketahun. Faktor kerusakan padang lamun terbesar disebabkan oleh aktitivias manusia (Grech et al., 2012). Potensi padang lamun didaerah ini perlu pengelolaan yang baik oleh pemangku kebijakan, agar ekosistem ini bisa terjaga dan dapat dimanfaatkan secara berkelanjutan. Oleh karena itu, penelitian mengenai studi komunitas lamun di lokasi ini perlu dilakukan. Penelitian ini akan mengkaji beberapa aspek terkait komunitas lamun seperti jenis, kerapatan dan indeks ekologi lamun.

\section{METODE PENELITIAN}

Penelitian ini dilakasanakan pada bulan Agustus 2021, di Kecamatan Tanggetada, Kabupaten Kolaka. Lokasi penelitian tebagi atas 3 Stasiun berdasarkan keberadaan padang lamun (Gambar 1). Stasiun 1 berada di Kelurahan Tanggetada, Stasiun 2 di Desa Palewai dan Stasiun 3 Kelurahan Anaiwoi.

Pengambilan data lamun mencakup pengambilan data jenis dan kerapatan lamun. Pengambilan data ini mengacu kepada metode pengamatan lamun Rahmawati et al, (2014), dengan menggunakan transek kuadrat $50 \times 50 \mathrm{~cm}$ pada transek garis sepanjang $100 \mathrm{~m}$ dengan jarak tiap transek garis adalah 50 $\mathrm{m}$. Pengamatan atau pengidentifikasian jenis lamun dilakukan langsung secara di lapangan, jenis lamun yang ada dalam plot transek diidentifikasi dengan melihat bentuk daun, rhizoma bunga dan buah (Mckenzie, 2003; Waycott et al., 2004).

Data parameter lingkungan yang diamati pada penelitian ini mencakup suhu, arus, salinitas dan jenis substrat. 
Pengambilan data parameter lingkungan berupa suhu, arus dan salinitas dilakukan secara langsung di setiap stasiun penelitian dengan 3 kali pengulangan. Sedangkan parameter substrat, sampel yang telah diambil di setiap lokasi penelitian dianalisis ukuran tekstur nya pada skala laboratorium yang ditentukan menggunakan skala Wenworth (Wenworth, 1992).

Kerapatan yaitu jumlah total individu dalam suatu unit area yang diukur. Kerapatan lamun dihitung dengan persamaan (English et al., 1997):

$$
\mathrm{D}=\mathrm{n} / \mathrm{A}
$$

Keterangan :

D: $\quad$ Kerapatan lamun (Ind/m2)

$\mathrm{N}$ : Jumlah total individu (Individu)

A : $\quad$ Luas total transek $(\mathrm{m} 2)$
Tabel 1. Kategori Kerapatan Lamun (Braun-Blanquet, 1965)

\begin{tabular}{lcl}
\hline Skala & $\begin{array}{c}\text { Kerapatan } \\
\left(\text { ind } / \mathbf{m}^{2}\right)\end{array}$ & \multicolumn{1}{c}{ Kondisi } \\
\hline 5 & $>175$ & Sangat rapat \\
4 & $125-175$ & Rapat \\
3 & $75-25$ & Agak rapat \\
2 & $25-75$ & Jarang \\
1 & $<25$ & Sangat Jarang \\
\hline
\end{tabular}

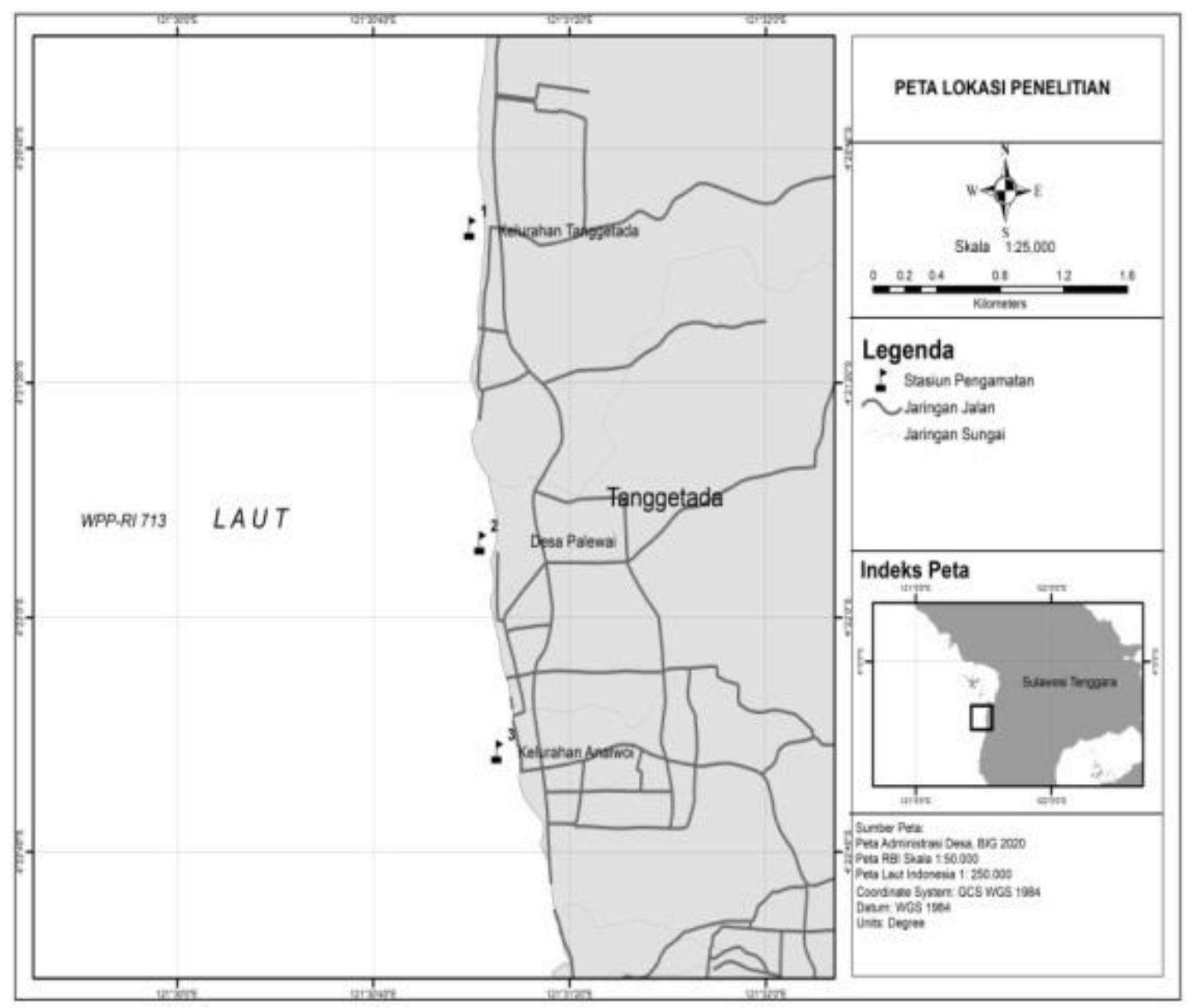

Gambar 1. Peta Lokasi Penelitian 
Indeks keanekaragaman lamun $\left(\mathrm{H}^{\prime}\right)$ dihitung dengan menggunakan rumus Shannon and Weiner (1949) dalam Odum (1993) dihitung menggunakan formula sebagai berikut:

Keterangan :

$$
\mathrm{H}^{\prime}=-\sum n \mathrm{n} / \mathrm{N} \mathrm{x} \text { In ni/N }
$$

H' : Indeks keanekaragaman jenis

ni : Jumlah individu setiap jenis

$\mathrm{N}$ : Jumlah total individu

Indeks keanekaragaman digolongkan dalam kriteria sebagai berikut:

$\mathrm{H}^{\prime} \leq 2$ : Keanekaragaman kecil

$2<\mathrm{H}^{\prime} \leq 3$ : Keanekaragaman sedang

$\mathrm{H}^{\prime}>3$ : Keanekaragaman tinggi

Indeks kesekaragaman lamun (E) dihitung dengan menggunakan rumus Shannon and Weiner (1949) dalam Odum (1971) dihitung menggunakan formula sebagai berikut:

Keterangan :

$$
\mathrm{E}=\mathrm{H}^{\prime} / \mathrm{Ln} \mathrm{S}
$$

E : Indeks keseragaman jenis

H' : Indeks keanekaragaman jenis

$\mathrm{S} \quad$ : Jumlah jenis

Nilai Indeks keseragaman berdasarkan Krebs, (1972) dikategorikan sebagai berikut:

$0<\mathrm{E} \leq 0.5:$ Komunitas tertekan

$0.5<\mathrm{E} \leq 0.75$ : Komunitas labil

$0.75<\mathrm{E} \leq 1:$ Komunitas stabil

Indeks dominasi lamun dihitung dengan menggunakan rumus odum 1971:

$$
\mathrm{C}=\sum(\mathrm{ni} / \mathrm{N})
$$

Keterangan :

C : Indeks dominasi

ni : Jumlah individu setiap spesies

$\mathrm{N}$ : Jumlah total individu

Nilai indeks dominansi

dikelompok-kan dalam 3 kriteria, yaitu:

$0<\mathrm{C}=0.5$ : Dominansi rendah

$0.5<\mathrm{C}=0.75$ : Dominansi sedang

$0.75<\mathrm{C}=1:$ Dominansi tinggi

\section{HASIL DAN PEMBAHASAN}

\section{Parameter Lingkungan}

Kondisi mengenai parameter lingkungan perairan dapat dilihat pada (Tabel 1). Suhu perairan pada penelitian ini berkisar antara $28-31^{\circ} \mathrm{C}$. Menurut Lee et al. (2007) suhu optimal untuk pertumbuhan lamun pada daerah tropis berkisar antara $23-32^{\circ} \mathrm{C}$. Kodisi suhu yang melewati nilai optimum akan meyebabkan lamun tersebut mengalami stress dan akhirnya mati, karena lamun tersebut akan lebih banyak melakukan proses respirasi, sehingga tingkat fotosisntesisnya sangat rendah (Marsh et al., 1986, Staehr \& Borum, 2011).

Salinitas merupakan salah satu faktor yang mempengaruhi distribusi dan tingkat kelangsungan hidup pada lamun (Salo dan Pedersen, 2014). Salinitas perairan pada penelitian ini berkisar antara 29-32 ppt. Salinitas yang melebihi batas optimum dapat mengurangi biomassa lamun dan secara langsung membatasi pertumbuhan lamun dengan cara menghambat pembentukan fotosintesa dan protein (Flowers, 1985, Walker, 1985).

Tabel 1. Parameter Lingkungan

\begin{tabular}{lccc}
\hline \multicolumn{1}{c}{ Parameter } & Stasiun 1 & Stasiun 2 & Stasiun 3 \\
\hline Suhu $\left({ }^{0} \mathrm{C}\right)$ & 26 & 27 & 27 \\
Salinitas (ppt) & 30 & 30 & 30 \\
Arus $(\mathrm{m} /$ detik) & 0.054 & 0.078 & 0.031 \\
Substrat & Pasir berlumpur & Pasir berlumpur & Lumpur Berpasir \\
\hline
\end{tabular}


Kecepatan arus pada penelitian ini berkisar antara 0.031-0.054 $\mathrm{m} /$ detik. Salah satu fungsi lamun yaitu meredam pergerakan arus diperairan sehingga bisa substrat lebih stabil (Hemminga \& Duarte, 2000). Kecepatan arus dapat mempengaruhi pertumbuhan morfometrik daun, akar dan rhizome lamun (Schanz \& Asmus, 2003)

Tipe substrat dasar perairan pada penelitian ini adalah Pasir berlumpur dan lumpur berpasir. Menurut Nienhuis et al. (1989), lamun dapat tumbuh pada substrat berpasir, lumpur berpasir, berlumpur, dan kadang-kadang ditemukan pada daerah pecahan karang mati.

\section{Jenis Lamun}

Ditemukan 6 jenis lamun dari 2 family yang tersebar di 3 stasiun berbeda yaitu Enhalus acoroides, Thalassia hemprichii, Cymodocea rotundata, Halodule uninervis, Halophila ovalis, dan Syringodium isoetifolium (Tabel 2). Berbeda dengan penelitian yang dilakukan oleh Ikhsan et al, (2019) di pulau Wanci, yang menemukan 7 jenis lamun yang terdiri dari Cymodocea rotundata, Halodule uninervis, Thalassodendron ciliatum, Syringodium isoetifolium, Thalassia hemprichii, Enhalus acoroides dan Halophila ovalis.
Perbedaan karakteristik lingkugan merupakan faktor yang membedakan komposisi jenis lamun pada suatu habitat (Short \& Coles, 2001).

Berdasarkan hasil pengamatan, lamun di Perairan Tanggetada memiliki penyebaran secara berkelompok dan membentuk vegetasi lamun campuran atau vegetasi multispesies. Menurut Short et al, (2007), padang lamun di daerah tropis indo-pacific pada umumnya membentuk vegetasi lamun campuran (multispesies). Beberapa studi mengungkapkan bahwa lamun dengan vegetasi multispesies memberikan kotribusi produksi lebih tinggi di bandingkan vegetasi monospesies, sehingga sangat berperan penting terhadap biota-biota yang hidup disekitarnya (Erftemeijer \& Stapel, 1999; Huang et al, 2015). Jenis lamun Enhalus acoroides dan Thalassia hemprichii merupakan jenis lamun yang tersebar merata disetiap stasiun pengamatan, kedua jenis lamun tersebut merupakan spesies klimaks dalam suksesi pembentukan komunitas padang lamun, yang memiliki ukuran morfologi relative besar dan memiliki daya adaptasi yang baik terhadap perubahan lingkungan (Hemminga \& Duarte, 2000; Rizqi, 2021).

Tabel 2. Jenis dan sebaran Lamun.

\begin{tabular}{lccc}
\hline \multirow{2}{*}{ Family/ Spesies } & \multicolumn{3}{c}{ Lokasi } \\
\cline { 2 - 4 } Hydrocharitaceae & Stasiun 1 & Stasiun 2 & Stasiun 3 \\
Enhalus acoroides & & & \\
Thalassia hemprichii & + & + & + \\
Halophila ovalis & + & + & + \\
Potamogetonaceae & + & & \\
Cymodocea rotundata & & + & \\
Halodule uninervis & + & + & \\
Syringodium & + & & \\
isoetifolium & + & + & \\
\hline
\end{tabular}




\section{Kerapatan Lamun}

Kerapatan lamun pada setiap stasiun penelitian menunjukkan pada skala kategori rapat sampai jarang (Braun-Blanquet,1965). Kerapatan lamun paling tinggi ditemukan pada stasiun 1 dengan nilai rata-rata kerapatan 160.46 $\mathrm{Ind} / \mathrm{m}^{2}$ dan paling rendah pada stasiun 3 yaitu $60.59 \mathrm{Ind} / \mathrm{m}^{2}$ (Gambar. 2). Di lokasi berbeda, Monita et al, (2021) menemukan bahwa kerapatan lamun di Teluk Awur berkisar antara $164-196 \mathrm{ind} / \mathrm{m}^{2}$.

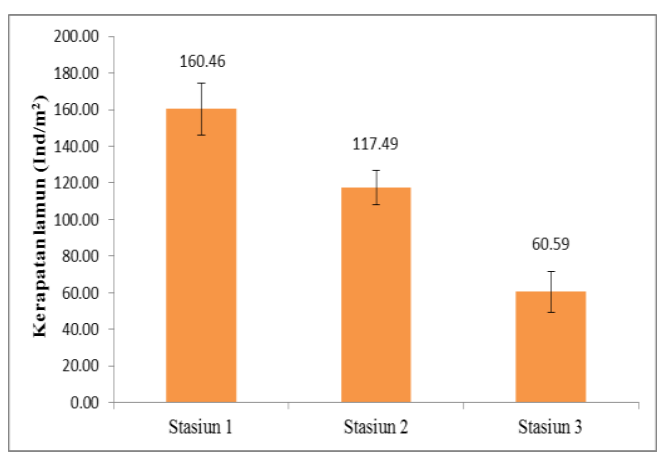

Gambar 2. Kerapatan Lamun (Ind/ $\left./ \mathrm{m}^{2}\right)$

Kerapatan lamun dipengaruhi oleh jenis lamun penyusunnya, kondisi parameter fisik-kimia perairan, dan faktor-faktor antropogenik yang mempengaruhi suatu lingkungan (Short dan Coles, 2001; Grech et al., 2012). Stasiun 3 tersusun atas lamun Enhalus acoroides, Thalassia hemprichii, dan Cymodocea rotundata, dimana Enhalus acoroides paling banyak ditemukan di lokasi ini. Enhalus acoroides memiliki morfologi dan knopi daun yang besar, namun pada lokasi penelitian ditemukan bahwa lamun ini tumbuh saling berjarak antara tiap tegakan. Selain itu faktor subtrat dengan tipe lumpur berpasir juga mempengaruhi kondisi lamun lokasi ini. Substrat tipe ini sangat labil dan mengakibatkan tingginya kekeruhan di lokasi tersebut, sehingga menghambat penetrasi cahaya yang dibutuhkan lamun untuk melakukan fotosintesis (Fahrudin, 2017). Selain itu, lokasi stasiun 3 berada dekat dengan pemukiman dan dermaga kapal nelayan, sehingga sangat rentan mengalami degradasi.
Lamun jenis Thalassia hempricii memiliki kerapatan yang paling tinggi diantara jenis lamun lainnya (Gambar 2).

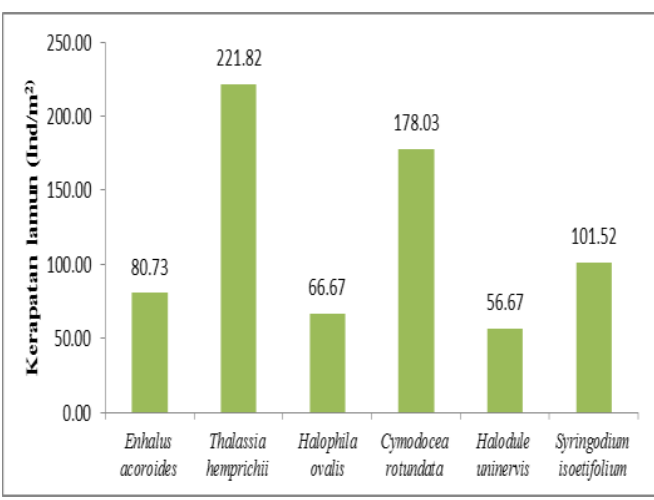

Gambar 2. Kerapatan Lamun per jenis (Ind $/ \mathrm{m}^{2}$ )

Thalassia hempricii ditemukan disetiap transek pengamatan dengan nilai kerapatan rata-rata $221.82 \mathrm{Ind} / \mathrm{m} 2$.

Beberapa penelitian menunjukkan, Thalassia hempricii merupakan jenis lamun yang paling luas sebarannya dengan kerapatan di berbagai lokasi sangat tinggi, seperti penelitian Fahruddin et al, (2017) di Pesisir Desa Bahoi dan Kawaroe et al, (2016) di Kepulauan Seribu. Menurut Hutomo et al. (1988), Thalassia hemprichii merupakan lamun yang paling dominan dan sebarannya ditemukan hampir diseluruh perairan Indonesia, mendominasi vegetasi campuran dan dapat ditemukan pada kedalaman mencapai 25 meter.

Thalassia hempricii merupakan jenis lamun yang sangat mentolelir kondisi substrat, dan bisa hidup pada semua kondisi tipe substrat di perairan (Kawaroe et al., 2016). Thalassia hempricii memiliki rhizoma dan akar yang kuat dengan knopi daun yang lebar sehingga kemampuan adaptasi terhadap tipe substrat dan variasi kondisi lingkungan sangat baik. 


\section{Indeks Keanekaragaman, Keseragaman dan Dominansi Lamun}

Indeks keanekaragaman lamun pada semua stasiun berkisar antara 0.95 - 1.60 . Berdasarkan kriteria, indeks keanekargaman lamun pada penelitian ini masuk kategori rendah (Krebs, 1989), dimana hanya ditemukan 6 jenis lamun dari 13 jenis lamun yang ada di Indonesia. Parameter lingkungan dan aktivias manusia merupakan faktor sehingga tidak semua jenis lamun dapat hidup di lokasi penelitian. Indeks keseragaman lamun berkisar antara $0.53-0.89$.

Tabel 3. Indeks Keanekargaman, Keseragaman dan Dominansi Lamun

\begin{tabular}{cccc}
\hline \multirow{2}{*}{ Lokasi } & \multicolumn{3}{c}{ Indeks ekologi } \\
\cline { 2 - 4 } & Keanekaragaman & Keseragaman & Dominansi \\
\hline Stasiun 1 & 1.56 & 0.87 & 0.25 \\
Stasiun 2 & 1.60 & 0.89 & 0.23 \\
Stasiun 3 & 0.95 & 0.53 & 0.41 \\
\hline
\end{tabular}

Stasiun 1 dan 2 menunjukkan nilai keseragaman yang tinggi yang menandakan bahwa kondisi komunitas lamun pada lokasi tersebut stabil. Sedangkan stasiun 3 menunjukkan nilai keseragaman sedang, yang artinya komunitas lamun pada lokasi tersebut pada kondisi labil. Indeks dominasi lamun pada penelitian ini berkisar antara 0.25 0.41. dan masih dalam kategori rendah. Artinya tidak ada spesies lamun yang mendominasi pada komunitas lamun di lokasi penelitian.

\section{KESIMPULAN}

Total 6 jenis lamun di perairan kecamatan Tanggetada yang terdiri dari Enhalus acoroides, Thalassia hemprichii, Cymodocea rotundata, Halodule uninervis, Halophila ovalis, dan Syringodium isoetifolium. Kerapatan lamun termasuk dalam kategori rapat dan jarang. Stasiun 1 yang berada pada KelurahanTanggetda memiliki kondisi lamun dengan kerapatan tinggi dengan ketegori rapat, sedangkan stasiun 3 Kelurahan Anaiwoi dengan kerapatan lamun yang rendah dengan kategori jarang.

\section{UCAPAN TERIMA KASIH}

Penulis mengucapkan terima kasih kepada Direktorat Jenderal Pendidikan Tinggi Kemendikbud-Ristek sebagai pemberi dana melalui mekanisme penelitian dosen pemula Tahun anggaran 2020.

\section{DAFTAR PUSTAKA}

Azkab, M.H. (2006). Ada Apa dengan Lamun. Pusat Penelitian Oseanografi-LIPI. Jurnal Oseana. 31(3): 45-55.

Braun-Blanquet, J.., (1965)., Plant Sociology: The Study of Plant Communities, (Trans. rev. and ed. by C.D. Fuller and H.S. Conard), Hafner, London.

Christianen, M.J.A., Herman, P.M.J., Bouma, T.J,. Lamers, L.P.M., Van Katwijk,M.M,. Van der Heide T., Mumby, P.J.., Silliman, B.R.., Engelhard S.L., Van de Kerk., Kiswara W., \& Van de Koppel J. (2014). Habitat Collapse Due To Overgrazing Threatens Turtle Conservation In Marine Protected Areas. Proceeding of The Royal Society. B. 281, 20132890. doi: 10.10 98/rspb.2013.2890.

Duarte, C.M., J.J. Middelburg \& N.F.Caraco. (2005). Major Role Of Marine Vegetation On The Oceanic Carbon Cycle. Biogeo sciences. 2(1): 1-8.

English, S.C., Wilkinson, and V. Barker. (1994). Survey Manual For Tropical Marine Resources. 
Austalian Institute of Marine Science. Townswile. 367 pp.

Erftemeijer, PA., Stapel, j., (1999). Primary Production Of DeepWater Halophile Ovalis ovalis Meadow. Aquatic Botany. 65:, 7182.

Fahruddin, M. F., Yulianda. \& Setyobudiandi, I. (2017). Kerapatan Dan dan Penututupan Ekosistem Lamun di Pesisir Desa Bahoi, Sulawesi Utara. Jurnal Ilmu dan Teknologi Kelautan Tropis. 9(1):375-383.3.

Flowers, T. (1985). Physiology Of of Halophytes. Plant and Soil. 89(13): 41-56.

Grech, A, Chartrand-Miller, K. Erftemeijer P., Fonseca, M. McKenzie, L., Rasheed, M.., Taylor, H., Coles, R. (2012). A Comparison Of Threats, Vulnerabilities And Management Approaches iIn Global Seagrass Bioregions. Environment Research Letter. 7(2). 1-8.

Hemminga, M.A., and \& Duarte, C.M. (2000). Seagrass Ecology. Cambridge University Press, Cambridge.

Huang, Y. H., C. L. Lee,. C. Y. Chung,. S. C. Hsiao,. H. J. Lin. (2015). Carbon budgets Budgets of multispecies Multispecies seagrass Seagrass beds at Dongsha island Island in the The south South China Sea. Marine Environmental Research, 106: 92-102.

Hutomo. (1985). Telaah Ekologi Komunitas Ikan pada Padang Lamun di Teluk Banten. Fakultas Pasca Sarjana. IPB. Bogor. 271 hal.

Ikhsan, N. Zamany, P.N. Soedharma, D. (2019). Struktur Komunitas Lamun Di Pulau Wanci, Kabupaten Wakatobi, Sulawesi Tenggara. Jurnal Teknologi Perikanan dan Kelautan. 10(1):2738

Kawaroe, M., A.H. Nugraha, Juraij, and I.A. Tasabaramo. (2016). Seagrass Biodiversity At Three Marine
Ecoregions of Indonesia: Sunda Shelf, Sulawesi Sea, and Banda Sea. Biodiversitas. 17(2):585-591.

Kiswara, W \& M. Hutomo. 1985. Habitat dDan Sebaran Geografik Lamun. Jurnal Oseana. 12(1): 21- 30

Koch, E.W., Booth, D.M., \& Palinkas, C. (2012). Seagrasses and the ecosystem service of shoreline protection (or is it sediment stabilization?). In: Creed, J.C., \& Oigman Pszczol, S.S. (Eds.), Proc. 10th Int. Seagrass Biology Workshop (ISBW10), 25-30 Nov. 2012. Armac, ão dos Búzios, Brazil. Instituto Biodiversidade Marinha, Rio deJaneiro, Brazil, $108 \mathrm{hlm}$.

Krebs CS. (1972). Ecology. The Experimental Analysis oOf Distribution And Abudance. New York: Harpers and row publisher.

Krebs, C.J. (1989). Ecological Methodology. Harper Collins Publishers. Inc., New York

Kuo, J. (2007). New Monoecious Seagrass Of Halophila Sulawesii (Hydrocharitaceae) From Indonesia. Aquatic Botani. 87 (2): 171-175.

Lee, K-S., Park, S.R., Kim, Y,K. (2007). Effects oOf Irradiance, Temperature, Aand Nutrients oOn Growth Dynamics oOf Seagrasses: a review. Journal of Experiment Marine Biology and Ecology. 350(1):144-175.

Marsh, J.A., Dennison, W.C., Alberte, R.S. (1986). Effects of temperature on photosynthesis and respiration in eelgrass (Zostera marina L.). Journal of Experiment Marine Bioogy and Ecology. 101(3):257267.

McKenzie, L.J. (2003). Guidelines For The Rapid Assessment aAnd Mapping Oof Tropical Seagrass Habitats. QFS, NFC, Caims. Queensland. 46 pp.

Monita, D., Endrawati, H., Riniatsih, I. (2021). Bioekologi Lamun di Perairan Teluk Awur, Jepara, Jawa 
Tengah. Journal of Marine Research. 10 (2). 165-174.

Nienhuis, P., Coosen, J., Kiswara, W. (1989). Community Structure And Biomass Distribution oOf Seagrasses and Macrofauna in the Flores Sea, Indonesia. Netherlands Journal of Sea Research. 23(2):197-214.

Odum EP. (1971). Fundamental ecology 3 rd. W.B Sanders Company. Philadelphia, 574 ppHal.

Odum, E.P. (1971). Fundamental of Ecology. 3rd ed. W.B. Saundes Company. Tokyo, Japan. 574 Hal.

Odum, E.P. (1993). Dasar-dasar Ekologi. Terjemahan Tjahjono Samingan. Edisi Ketiga. Yogyakarta: Gadjah Mada University Press.

Oktawati, N.O., Sulistianto, E., Fahrizal, W \& Maryanto, F. (20180. Nilai Ekonomi Ekosistem Lamun Di di Kota Bontang. EnviroScienteae. 14(3). 228-236.

Rahmawati, S. Irawan, A. Supriyadi, I. H. \& Azkab, M. H. (2014). Panduan Monitoring Padang Lamun. Pusat Penelitian Oseanografi LIPI: Jakarta. 32 Hal.

Rizqi, (2021). The Condition of Seagrass Beds in North Sulawesi Following the Implementation of Community-Based Coastal Management Program. Iop conf. Series: earth and environmental science. 789 (2021) 012013.

Salo, T., Pedersen, M.F. (2014). Synergistic Effects of Altered Salinity aAnd Temperature on Estuarine Eelgrass (Zostera marina) Seedlings and Clonal Shoots. Journal of Experiment Marine Biology and Ecology. 457: 143-150.

Schanz, A. , Asmus H. (2003). Impact of Hydrodynamics On Development aAnd Morphology of Intertidal Seagrasses in the Wadden Sea. Marine Ecology Program Series. 261(1):123-134.

Short, F., F Carruthers, W. Dennisa \& M. Waycott. (2007). Global Seagrass Distribution and Diversity a
Bioregional Model. Jounal Experiment Marine Biology Ecology. 350:3-20.

Short, F.T. and R.G. Coles. (2001). Global seagrass research methods. Elsevier, Amsterdam.

Staehr, P.A., Borum, J. (2011). Seasonal Acclimation in Metabolism Reduces Lightrequirements of Eelgrass (Zostera marina). Journal of Experiment Marine Biology and Ecology. 407(2): 139-146.

Supriadi,S., Kaswadji, R.F., Bengen, D.G. \& Hutomo, M. (2014). Carbon Stock of Seagrass Community in Barranglompo Island, Makassar. Indonesian Journal of Marine Sciences, 19(1):1-10.

Vo, S.T., Pernetta, J.C \& Paterson, C.J. (2013). Status and Trends in Coastal Habitats of the South China Sea. Ocean \& Coastal Management. 85:153-163.

Walker, D., Lukatelich, R., Bastyan, G., McComb, A. (1989). Effect of Boat Moorings on Seagrass Beds Near Perth, Western Australia. Aquatic Botani. 36(1):69-77.

Wawo, M., Adrianto, L., Bengen, D. G \& Wardiatno, Y. (2014). Valuation of Seagrass Ecosystem Services in Kotania Bay Marine Nature Tourism Park, Western Seram, Indonesia. Asian Journal of Scientific Research. 7(4 ): 591600.

Waycott, M., McMahon, K., Mellors, J., Calladine, A., Kleine, D. (2004). A Guide to Tropical Seagrasses of The Indo-West Pacific. Townsville: James Cook University. Townsville Queensland. Australia. 72 Hal. 
